\title{
WAJAH ISLAM NUSANTARA PADA TRADISI PETA KAPANCA DALAM PERKAWINAN ADAT BIMA
}

\author{
Muhammad Aminullah dan Nasaruddin \\ Institut Agama Islam Muhammadiyah Bima \\ Email: amienmuhammad.ma@gmail.com
}

\section{Abstrak}

Penyelenggaraan peta kapanca dalam masyarakat Bima telah menjadi bagian dari tradisi masyarakat. Hadirnya peta kapanca dalam perkawinan adat Bima, merupakan bagian dari respon masyarakat terhadap kebudayaan yang berbasis Islam. Bentuk-bentuk akulturasi Islam dengan budaya Bima atau dalam istilah lain disebut dengan pribumisasi Islam pada tradisi peta kapanca dapat dilihat pada; pertama, pembacaan shalawat dan do'a pada saat dimulainya prosesi boho oi mbaru atau mandi uap dengan bunga-bunga. Kedua, iringan hadrah pada saat prosesi kalondo wei. Ketiga, pembacaan kalam ilahi yang kemudian dilanjutkan dengan jiki kapanca yang berisi pembacaan maulid syaraful anam saat prosesi peta kapanca. Keempat, prosesi peta kapanca yang berjumlah ganjil, melambangkan bahwa Allah swt. menyukai sesuatu yang ganjil dan hiasan bunga-bunga telur yang berjumlah sembilan buluh sembilan buah, melambangkan asmaul husna. Proses pribumisasi Islam pada tradisi peta kapanca itulah yang kemudian membentuk pola atau corak Islam yang khas Bima yang merupakan wajah Islam Nusantara.

Kata Kunci: Akulturasi, Budaya Bima, Peta Kapanca

\section{Pendahuluan}

( 7 ejak awal perkembangannya Islam di Indonesia telah menerima akomodasi budaya. Karakter Islam Indonesia menunjukkan adanya kearifan lokal di Indonesia yang tidak bertentangan dengan ajaran Islam, namun justru menggandengkan ajaran Islam dengan adat istiadat lokal yang banyak tersebar di wilayah Indonesia. Pertemuan Islam dengan adat dan tradisi Indonesia itu kemudian membentuk sistem sosial, lembaga 
pendidikan, serta sistem kesultanan. Tradisi-tradisi itulah yang kemudian disebut dengan istilah Islam Nusantara, yakni Islam yang telah melebur dengan tradisi dan budaya Nusantara. Pemahaman tentang formulasi Islam Nusantara menjadi penting untuk memetakan identitas Islam di negeri ini. Islam Nusantara dimaksudkan sebagai pemahaman keislaman yang bergumul, berdialog dan menyatu dengan kebudayaan Nusantara, melalui proses seleksi, akulturasi dan adaptasi. Islam Nusantara tidak hanya terbatas pada sejarah atau lokalitas Islam di tanah Jawa. Lebih dari itu, akulturasi dan adaptasi Islam dengan budaya telah menyebar secara menyeluruh ke pelosok Nusantara, diantaranya di wilayah Bima yang merupakan daerah yang berada di ujung Timur Pulau Sumbawa, Provinsi Nusa Tenggara Barat.

Ditinjau dari aspek sejarah, Islam masuk ke Bima pada abad ke-17 melalui Sape untuk pertama kali yang dibawa oleh para Ulama dari Sumatera yang diutus oleh raja Goa, Tallo, Luwu, dan Bone. Semenjak itu terjadi perubahan corak kehidupan sosial masyarakat Bima yang diambil dari dasar-dasar ajaran agama Islam, sehingga dalam kehidupan masyarakat dalam berbagai aspek dijiwai dan diwarnai oleh ajaran Islam. Oleh sebab itu masyarakat Bima dewasa ini memiliki adat istiadat yang bercorak Islam sebagai warisan yang terus dilestarikan secara turun temurun semenjak Islam hadir hingga hari ini. Diantara adat-istiadat dan tradisi masyarakat Bima yang dimaksud adalah adat perkawinan, akad nikah, upacara khitanan, upacara khatam al-Qur'an, kesenian dan pakaian. ${ }^{1}$

Akulturasi Islam dengan budaya Bima, diantaranya terlihat dalam tradisi peta kapanca dalam perkawinan adat Bima. Tradisi peta kapanca merupakan salah satu tradisi yang ada sejak zaman dahulu dan telah melekat dengan kuat serta utuh di dalam tatanan kehidupan masyarakat adat Bima, bahkan beberapa kalangan masyarakat baik itu tokoh agama dan tokoh masyarakat adat itu

${ }^{1}$ M. Fachrir Rahman, Islam di Bima; Kajian Historis tentang Proses Islamisasi dan Perkembangannya sampai Masa Kesultanan (Yogyakarta: Genta Press, 2008), 35-37. 
sendiri menyatakan bahwa jika tidak melaksanakan upacara adat ini akan menjadi aib bagi keluarga dan masyarakat setempat. Kapanca berasal dari kata daun pacar yang berarti menempelkan, jadi kapnaca berarti menempelkan daun pacar (inai) pada kuku pengantin perempuan yang dilakukan oleh tujuh wanita adat. Upacara kapanca ini merupakan salah satu rangkaian upacara terpenting pada prosesi perkawinan adat Bima sebagai tradisi budaya Bima yang melekat dalam upacara perkawinan.

Sebelum Islam hadir di Bima, tidak terdapat prosesi zikir dan do'a dalam tradisi peta kapanca. Namun, setelah Islam manjadi agama masyarakat Bima, semenjak itulah terjadi akulturasi ajaran Islam berupa zikir dan do'a kedalam tradisi peta kapanca, yang pada akhirnya zikir dan do'a dalam tradisi peta kapanca dikenal dengan istilah jiki kapanca. Lebih lanjut, tradisi peta kapanca dalam perkawinan adat Bima yang kemudian menjadi bagian dari tradisi Islam Nusantara, menjadikan alasan peneliti untuk meneliti tentang kajian ini di Bima. Fakta lain yang mendukung pentingnya penelitian ini juga dilihat dari corak kehidupan sosial masyarakat Bima yang sangat kental dengan nilai-nilai agama serta budaya turun temurun. Ketika Islam masuk ke Bima pada abad ke-17, maka terjadi perubahan corak kehidupan sosial masyarakat Bima yang diambil dari dasar-dasar ajaran agama Islam, sehingga dalam kehidupan masyarakat dalam beberapa aspek dijiwai dan diwarnai oleh ajaran Islam. ${ }^{2}$

Dari berbagai masalah tersebut penulis berusaha mengungkap dan memaparkan bagaimana proses pelaksanaan peta kapanca dalam perkawinan adat Bima, sehingga menjadi bagian dari tradis masyarakat. Bagaimana bentuk-bentuk akulturasi Islam dengan budaya Bima pada tradisi peta kapanca dalam perkawinan adat Bima, sehingga menjadi bagian dari tradisi Islam Nusantara.

${ }^{2}$ M. Fachrir Rahman, Islam di Bima; Kajian Historis tentang Proses Islamisasi dan Perkembangannya sampai Masa Kesultanan,.... 35. 


\section{Islam Nusantara dan Pribumisasi Islam}

Islam Nusantara merupakan Islam yang bercirikan Indonesia, yang memiliki gabungan antara nilai Islam teologis dengan nilainilai tradisional lokal, budaya, dan adat Istiadat di Tanah Air. Karakter Islam Nusantara menunjukkan adanya kearifan lokal di Nusantara yang tidak melanggar ajaran Islam, namun justru menyelaraskan ajaran Islam dengan adat istiadat lokal yang banyak tersebar di wilayah Indonesia. Kehadiran Islam tidak untuk merusak atau menantang tradisi yang ada. Sebaliknya, Islam datang untuk memperkaya dan mengislamkan tradisi dan budaya yang ada secara tadriji (bertahap). Hal ini tentunya membutuhkan waktu puluhan tahun atau bahkan sampai beberapa generasi. Pertemuan Islam dengan adat dan tradisi Indonesia itu kemudian membentuk sistem sosial, lembaga pendidikan, serta sistem kesultanan. Tradisi-tradisi itulah yang kemudian disebut dengan istilah Islam Nusantara, yakni Islam yang telah melebur dengan tradisi dan budaya Nusantara. ${ }^{3}$

Islam Nusantara merupakan sebuah pemahaman keislaman yang bergumul, berdialog dan menyatu dengan kebudayaan Nusantara, dengan melalui proses, akulturasi dan adaptasi. Lebih dari itu, Islam Nusantara adalah Islam yang ramah, terbuka, inklusif dan mampu memberi solusi terhadap masalah-masalah besar bangsa dan Negara. Islam yang dinamis dan bersahabat dengan lingkungan kultur, sub-kultur, dan agama yang beragam. Islam bukan hanya dapat diterima oleh orang Nusantara, tetapi juga pantas mewarnai budaya Nusantara untuk mewujudkan sifat akomodatifnya yakni rahmatan lil 'alamin. ${ }^{4}$

Sebagai bagian dari proses kebudayaan, masuknya agama Islam ke suatu wilayah akan selalu menjalani proses perjumpaan dengan kebudayaan-kebudayaan lokal, khususnya di Nusantara.

${ }^{3} Z$ Zainul Milal Bizawie, "Islam Nusantara Sebagai Subjek dalam Islamic Studies: Lintas Diskursus dan Metodologis", dalam Akhmad Sahal, dkk, Islam Nusantara; Dari Ushul Figh Hingga Paham Kebangsaan, (Bandung: Mizan, 2015), 240.

${ }^{4}$ Ibid. 
Berbagai ekpresi kebudayaan dan keislaman di nusantara merupakan hasil dari perjumpaan antara islam dan budaya lokal setempat. Abdurrahman Wahid pernah menelurkan konsepsi "pribumisasi Islam" untuk menjelaskan proses tak terelakkan ketika agama bertemu dengan budaya lokal tersebut. Pribumisasi dilakukan agar kita tidak tercerabut dari akar budaya. Sedangkan Islam dalam proses pribumisasi, mengakomodasi perjumpaan agama dan budaya yang bersifat alami.

Konsep pribumisasi Islam secara geneologis digagas pertama kali oleh Abdurrahman Wahid pada tahun 1980-an. Semenjak itu, Islam pribumi menjadi perdebatan menarik dalam lingkungan para intelektual; baik intelektual senior (tua) dengan intelektual muda. Dalam pribumisasi Islam tergambar bagaimana Islam sebagai ajaran normatif yang bersumber dari Tuhan diakomodasikan ke dalam kebudayaan yang berasal dari manusia tanpa kehilangan identitasnya masing-masing, sehingga tidak ada lagi pemurnian Islam atau proses menyamakan dengan praktik keagamaan masyarakat Muslim di Timur Tengah. Bukankah arabisme atau proses mengidentifikasi diri dengan budaya Timur Tengah berarti mencabut akar budaya kita sendiri? Dalam hal ini, pribumisasi bukan upaya menghindarkan timbulnya perlawanan dari kekuatan budayabudaya setempat, akan tetapi justru agar budaya itu tidak hilang. Inti pribumisasi Islam adalah kebutuhan, bukan untuk menghindari polarisasi antara agama dan budaya, sebab polarisasi demikian memang tidak terhindarkan. ${ }^{5}$

Pribumisasi Islam telah menjadikan agama dan budaya tidak saling mengalahkan, melainkan berwujud dalam pola nalar keagamaan yang tidak lagi mengambil bentuk autentik dari agama, serta berusaha mempertemukan jembatan yang selama ini melintas antara agama dan budaya. Pada konteks selanjutnya, akan tercipta pola-pola keberagamaan (Islam) sesuai dengan konteks lokalnya

${ }^{5}$ Abdurrahman Wahid, "Pribumisasi Islam" dalam Akhmad Sahal, dkk, Islam Nusantara; Dari Ushul Figh Hingga Paham Kebangsaan, 34. 
dalam wujud "Islam Pribumi" sebagai jawaban dari "Islam Autentik" atau "Islam Purifikatif" yang ingin melakukan proyek arabisme di dalam setiap komunitas Islam di seluruh penjuru dunia. "Islam Pribumi" justru memberi keanekaragaman interpretasi dalam praktik kehidupan beragama (Islam) di setiap wilayah yang berbeda-beda. Dengan demikian, Islam tidak lagi dipandang secara tunggal, melainkan beraneka ragam. Tidak ada lagi anggapan Islam yang di Timur Tengah sebagai Islam yang murni dan paling benar, karena Islam sebagai agama mengalami historisitas yang terus berlanjut. $^{6}$

Terdapat tiga hal yang menjadikan "Islam Pribumi" berbeda dari Islam autentik. Pertama, "Islam Pribumi" memiliki sifat kontekstual, yakni Islam dipahami sebagai ajaran yang terkait dengan konteks zaman dan tempat. Perubahan waktu dan perbedaan wilayah menjadi kunci untuk menginterpretasikan ajaran. Dengan demikian, Islam akan mengalami perubahan dan dinamika dalam merespons perubahan zaman. Kedua, "Islam Pribumi" bersifat progresif, yakni kemajuan zaman bukan dipahami sebagai ancaman terhadap penyimpangan terhadap ajaran dasar agama (Islam), tetapi dilihat sebagai pemicu untuk melakukan respons kreatif secara intens. Ketiga, "Islam Pribumi" memiliki karakter liberatif, yaitu Islam menjadi ajaran yang dapat menjawab problem-problem kemanusiaan secara universal tanpa melihat perbedaan agama dan etnik. Islam tidak kaku dalam menghadapi realitas sosial masyarakat yang selalu berubah.

Menurut Abdurrahman Wahid Pribumisasi Islam merupakan suatu pemahaman yang mempertimbangkan kebutuhan-kebutuhan lokal didalam merumuskan hukum-hukum agama tanpa mengubah hukum itu sendiri. "Pribumisasi Islam" bukan suatu upaya meninggalkan norma demi budaya, tetapi agar norma-norma itu menampung kebutuhan-kebutuhan dari budaya dengan mempergunakan peluang yang disediakan oleh variasi pemahaman nass,

${ }^{6}$ Khamami Zada dkk., Islam Pribumi: Mencari Wajah Islam Indonesia, dalam Jurnal Tashwirul Afkar, No. 14 (Jakarta: Lakpesdam, 2003), 9-10. 
dengan tetap memberikan peranan kepada ushul al-figh dan qawa'id al-figh. Dalam hal ini, wahyu harus dipahami dengan mempertimbangkan faktor-faktor kontekstual, termasuk kesadaran hukum dan rasa keadilan. ${ }^{7}$

Dalam proses ini pembauran Islam dengan budaya tidak boleh terjadi, sebab berbaur berarti hilangnya sifat-sifat asli. Islam harus tetap pada sifat keislamannya. al-Qur'an harus tetap dalam bahasa Arab, terutama dalam salat, sebab hal ini telah merupakan norma. Sedangkan terjemahan al-Qur'an hanyalah dimaksudkan untuk mempermudah pemahaman, bukan menggantikan al-Qur'an itu sendiri. Dalam hal ini yang dipribumikan adalah manifestasi kehidupan Islam belaka, bukan ajaran yang menyangkut inti keimanan dan peribadatan formalnya. Tidak diperlukan al-Qur'an Batak dan Hadis Jawa. Islam tetap Islam, di mana saja berada. Namun tidak berarti semua harus disamakan bentuk luarnya. Proses pribumisasi Islam seperti itulah yang kemudian membentuk pola atau corak Islam Nusantara. Sebuah corak keberislaman yang moderat, damai, ramah, dan terbuka. Pribumisasi Islam adalah caranya, sedangkan Islam Nusantara adalah buahnya.

\section{Tinjauan Historical Islam Di Bima}

Daerah Bima berada di ujung Timur Pulau Sumbawa, salah satu pulau di wilayah Propinsi Nusa Tenggara Barat, selain Pulau Lombok dan pulau-pulau kecil lainnya. Bima terletak di tengahtengah Kepulauan Nusantara dan di tengah-tengah gugusan pulaupulau yang sebelum tahun 1950 bernama Sunda Kecil (Bali, NTB, dan NTT sekarang). Samudera Indonesia di Selatan, Laut Flores di Utara, Kabupaten Dompu dan Kabupaten Sumbawa di Barat, dan Selat Sape di Timur. ${ }^{8}$

Secara sosiologis dan antropologis budaya, Pulau Sumbawa tiga kali lebih luas dari Pulau Bali, dihuni oleh dua kelompok etnis, yaitu; 
etnis Samawa (Tau Samawa) yang menghuni bagian Barat (Kabupaten Sumbawa dan Kabupaten Sumbawa Barat) dan etnis Mbojo (Dou Mbojo) di bagian Tengah dan Timur (Kabupaten Bima, Kota Bima, dan Kabupaten Dompu). Pulau Sumbawa menjadi sangat penting mengingat keberadaannya di antara dua agama besar yang berbeda, yaitu; antara keyakinan agama Hindu (Bali) dan Kristen (Flores, NTT). Bila dilihat dari sisi administratif, Bima terbagi menjadi dua pemerintahan yaitu Kota Bima dan Kabupaten Bima. Kota Bima dibatasi oleh Kabupaten Bima di sebelah Utara, Timur dan Selatan, serta Teluk Bima di sebelah Barat. wilayah Kota Bima terbagi dalam lima wilayah kecamatan dengan 38 kelurahan, yaitu: Kecamatan Asakota (4 kelurahan), Kecamatan Rasanae Barat (6 kelurahan), Kecamatan Mpunda (10 kelurahan), Kecamatan Raba (10 kelurahan) dan Kecamatan Rasanae Timur (8 kelurahan). ${ }^{9}$ Berdasarkan data Badan Pusat Statistik Kota Bima ${ }^{10}$, jumlah penduduk daerah Kota Bima tahun 2012-2013 adalah 146.308 jiwa. Penduduk Kota Bima terdiri dari beragam suku (etnik), suku Mbojo (dou Mbojo) sekitar 75\% adalah penduduk mayoritas yang menghuni daerah Kota Bima.

Sedangkan Kabupaten Bima berseblahan dengan Kota Bima, secara geografis Kabupaten Bima berada pada posisi $117^{\circ} 40^{\prime \prime}$ $119^{\circ} 10^{\prime \prime}$ Bujur Timur dan 70³0" Lintang Selatan. Kabupaten Bima dibatasi laut Flores sebelah utara, selat Sape sebelah timur, samudera Indonesia sebelah selatan, dan Kabupaten Dompu sebelah Barat. Luas wilayah setelah pembentukan daerah Kota Bima berdasarkan Undang-undang Nomor 13 tahun 2002 adalah seluas $437.465 \mathrm{Ha}$ atau 4.394,38 $\mathrm{Km}^{2}$ (sebelum pemekaran $459.690 \mathrm{Ha}$ atau 4.596,90 $\mathrm{Km}^{2}$ ), dengan jumlah penduduk 419.302 jiwa dengan kepadatan ratarata 96 jiwa $/ \mathrm{Km}^{2}$. Secara umum kondisi sosial, adat-istiadat dan tradisi masyarakat Bima sebagaimana yang disebutkan dalam catatan BO Istana, bahwa Bima telah melewati berbagai macam sistem politik pemerintahan. Dimulai dari masa naka (zaman pra-

${ }^{9}$ Data Badan Pusat Statistik Kota Bima Tahun, 2012-2013.

${ }^{10}$ Ibid. 
sejarah), ${ }^{11}$ pada abad ke-8 M, Bima sudah berinteraksi dengan Raja Sanjaya ${ }^{12}$ di Jawa Tengah. ${ }^{13}$ Kemudian, masa ncuhi (proto-sejarah). Kata ncuhi berasal dari bahasa Mbojo yang sinonim dengan kata "ncuri"14 dan kata "suri"15. Secara terminologis kata ncuhi mengandung dua pengertian. Pertama; kepala suku atau pemimpin agama. Kedua, ncuhi adalah nama suatu zaman yang berlangsung sejak abad ke-8 M sampai dengan berlakunya sistem pemerintah kerajaan pada abad ke-11 M. ${ }^{16}$

Dari masa naka dan ncuhi, sistem pemerintahan Bima beralih menjadi sistem kerajaan. Kerajaan dipimpin oleh seorang tokoh yang dipilih melalui "mbolo ro dampa" (musyawarah). Tokoh terpilih diberi gelar "Sangaji" (Raja), dalam menjalankan tugas raja harus berpedoman pada norma agama dan sistem adat istiadat yang telah dianut bersama. Pemerintah kerajaan berubah perlahan bersamaan dengan masuknya Islam di tanah Bima. Pada tanggal 15 Rabi'ul Awal 1030 H (7 Februari 1621), Putra mahkota (Jena Teke) La ka'i (Abdul Kahir) dan tiga orang saudaranya mengucapkan dua kalimat syahadat dihadapan para mubalig. Sejak saat itu pemerintahan dijalankan berdasarkan ajaran Islam yang berlangsung selama \pm 310 tahun. ${ }^{17}$ Seiring dengan hal itu, masuknya Islam telah membawa dampak dan pengaruh yang besar pada corak pemerintahan dan tatanan sosial masyarakat Bima. Dari catatan BO Istana dikatakan, pada tanggal 11 Jumadil Awal 1028 H (26 April 1618) Islam pertama kali masuk melalui Sape. Mubalig yang bernama Daeng Mangali

\footnotetext{
${ }^{11}$ Hasil penelitian para arkeolog dari Balai Arkeologi Denpasar Bali yang melakukan penelitian pada Situs Wadu Nocu Renda (Prasasti batu tempat menumbuk padi di desa Renda) dan Wadu Nocu Ncera (Prasasti batu tempat menumbuk padi di desa Ncera) Kecamatan Belo, diketahui bahwa kehidupan telah dimulai sekitar 2500 tahun silam atau \pm 500 tahun SM.

${ }^{12}$ Tidak disebutkan dari kerajaan mana. Tercatat dalam BO ketika itu Bima dikalahkan oleh Raja Sanjaya di Jawa Tengah.

${ }^{13}$ M. Hilir Ismail, Kebangkitan Islam......,19.

${ }^{14}$ Ncuri artinya, tunas baru yang tumbuh dari dahan utama.

${ }^{15}$ Suri artinya, tunas yang baru tumbuh atau mekar.

${ }^{16}$ M. Hilir Ismail, Kebangkitan Islam......,21.

${ }^{17}$ Ibid., 22.
} 
bersama tiga orang utusan Sultan Gowa datang menyampaikan berita bahwa Raja Gowa, Tallo, Luwu, dan Bone telah memeluk Islam, dan kerajaan Bima diharapkan mengikuti jejak mereka. ${ }^{18}$ Kedatangan mubalig Islam itu tertulis di dalam kitab BO sebagai berikut:

Hijratun Nabi saw 1028 hari bulan Jumadil-awal telah datang dipelabuhan Sape saudara Daeng Mangali di Bugis Sape dengan orang Luwu dan Tallo dan Bone untuk berdagang. Kemudian pada malam hari datang menghadap Ruma Bumi Jara yang memegang Sape untuk menyampaikan Ci'lo kain bugis dan keris serta membawa agama Islam Kerajaan Gowa. Dan Tallo, dan Luwu, dan Bone sudah masuk Islam dan Daeng Malabo dan keluarganya sudah masuk Islam seluruhnya.

Sejak Ruma Ta Ma Bata Wadu dilantik menjadi sultan Bima yang pertama dengan gelar sultan Abdul Kahir, agama Islam menjadi kepercayaan hampir seluruh masyarakat Bima, hanya sebagian kecil saja yang tidak menerima dan memeluk agama Islam. Bahkan sampai sekarang ini agama Islam tetap menjadi kepercayaan mayoritas masyarakat Bima khususnya suku Mbojo. ${ }^{19}$ Suku Mbojo dikenal sebagai suku yang taat agama, hampir seluruh masyarakat menganut agama Islam. Suku Mbojo memiliki pandangan hidup "Maja Labo Dahu" yaitu malu dan takut melanggar larangan agama dan adat-istiadat. ${ }^{20}$ Jika terdapat masyarakat melanggar norma agama dan adat, misalnya, laki-laki beristri selingkuh (zina), maka dikenakan hukum agama $(\text { dera })^{21}$, hukum adat (senda $)^{22}$, dan sangsi sosial (dikucilkan atau diusir).

${ }^{18}$ Ibid.,56.

${ }^{19} \mathrm{M}$. Fachrir Rahman, Islam di Bima......,63.

${ }^{20} \mathrm{M}$. Hilir Ismail, Kebangkitan Islam.......,13.

${ }^{21}$ Hukuman di dera merupakan hukum syariat dalam Islam; dipukul atau dicambuk.

${ }^{22}$ Senda adalah hukuman yang dijatuhkan terhadap pelaku pembunuhan, penganiyaan, mencuri dalam istana, melanggar susila dalam istana, perzinaan, dan perbuatan makar. Juga diartikan sebagai hukum pembuangan atau diasingkan dari masyarakat umum, atau dijatuhi hukuman mati. Abdullah Tajib, Sejarah Bima ( Dana Mbojo) (Jakarta: Harapan Masa PGRI, 1995), 203. 
Islam hadir sebagai satu himpunan tata laku dan nilai yang membentuk kebudayaan baru bagi masyarakat dan gejolak kekuasaan Bima. Berbagai aspek pemikiran, spiritual, perilaku, dan moral menjadi tawaran yang menyegarkan bagi masyarakat dan kemelut kekuasaan kepada pewaris tunggal kerajaan Bima. Dalam perkembangannya Islam dijadikan sebagai peradaban kesultanan Bima, walaupun tidak serta merta memupus kebiasaan (kepercayaan atau budaya lama) masyarakat Bima beralih kepada agama Islam. Untuk lebih memperluas penyebaran dakwah, ulama dan pemerintah mencari strategi-strategi khusus untuk menyebarluaskan nilai Islam, dan strategi itu adalah asimilasi atau penggabungan antara nilai-nilai agama Islam dengan budaya masyarakat Bima. Sehingga antara peradaban dan kebudayaan tersebut menjadi satu dan searah dengan tujuan agama Islam. Lebih dari itu, Islam juga membawa satu konsep yang baru bagi kemaslahatan masyarakat Bima, yaitu konsep hidup mengenai hakikat yang berhubungan antara manusia dengan manusia, dan antara manusia dengan Tuhannya. Sejalan dengan itu, Islam juga memberikan satu konsep mengenai hakikat nilai-nilai dan hakikat dari manakah nilai-nilai itu perlu ditata dan diterima. Sehingga Islam datang bukan hanya ingin mengkonstruksi keyakinan jiwa masyarakat Bima, tetapi sekaligus merekonstruksi kepercayaan dan budaya yang menjadi satu pedoman masyarakat agar kembali kepada Tuhan yang hakiki. Islam juga mengajarkan para pemimpin Bima tentang kekuasaan tunggal dan mutlak hanya milik Allah. Di sinilah letak fungsi Islam sebagai social control bagi masyarakat. Artinya, Islam melalui ayatayat al-Qur'an menjadi solusi masalah sosial yang terjadi di tengahtengah masyarakat Bima. Di sisi lain, penyerapan nilai Islam ke dalam tradisi masyarakat memiliki tujuan jangka panjang, yaitu melakukan rekayasa sosial demi mencapai perubahan sosial yang lebih baik. Nilai-nilai baru yang diserap bersifat universal yang dapat diimplementasikan ajaran universal Islam. Ajaran universal ini yang perlu dielaborasi untuk melakukan reproduksi kebudayaan pada masa sekarang maupun yang akan datang. Karena tradisi adalah 
simbol atau media untuk mengimplementasikan ajaran universal Islam, sehingga akan terjadi perbedaan atau variasi antara masyarakat Islam yang satu dengan masyarakat Islam lainnya. Kebudayaan lokal akan selalu ada di dalam masyarakat mana pun dan harus mendapatkan perhatian khusus dalam membumikan Islam di tengah-tengah masyarakat, khususnya masyarakat Bima.

\section{Perkawinan Adat Bima}

Perkawinan merupakan salah satu pranata terpenting dalam kehidupan manusia, dengan perkawinan keberlangsungan keturunan manusia bisa terjamin dan sah menurut pandangan agama dan tata nilai yang berlaku dalam suatu masyarakat. Dalam setiap masyarakat mempunyai tradisi tersendiri untuk merayakan dan mensukseskannya. Hal ini pula turut berlaku dalam tradisi masyarakat Bima. Jika ditelurusi, tradisi upacara perkawinan di Bima biasanya dilaksanakan setelah musim panen dan pada bulan-bulan yang bersejarah menurut Islam, seperti bulan Maulud, Bulan Rajab, dan bulan Zulhijah. Sebelum dilaksanakannya pernikahan, terdapat proses melamar atau meminang yang harus melalui beberapa tahapan-tahapan tertentu. Tahapan-tahapan tersebut ialah sebagai berikut:

\section{Panati}

Dalam tradisi Bima pada umumnya, panati merupakan jalan pembuka menuju ke jenjang perkawinan. Panati adalah melamar atau meminang perempuan. Panati diawali datangnya utusan resmi dari pihak laki-laki menemui orang tua atau keluarga perempuan, untuk menanyakan apakah perempuan tersebut telah memiliki calon suami atau belum. Jika memperoleh jawaban bahwa perempuan tersebut berstatus bebas, maka akan dilakukan pendekatan selanjutnya untuk memastikan bahwa perempuan tersebut dapat dilamar atau tidak, bila lamaran diterima oleh pihak perempuan, maka pihak laki-laki melakukan apa yang disebut wi'i nggahi.

Wi'i nggahi artinya dimana lamaran tersebut disepakati bersama antara pihak keluarga laki-laki dan perempuan. Kemudian 
pada hari yang telah ditetapkan bersama, maka wi'i nggahi tersebut diresmikan dihadapan keluarga gadis dengan disaksikan oleh perangkat desa, tokoh masyarakat dan tokoh agama, dalam acara pita nggahi yaitu peresmian pertunangan antara laki-laki dan perempuan tersebut.

\section{Ngge'e Nuru}

Setelah dilakukannya acara pita nggahi (peresmian pertunangan), maka calon menantu laki-laki diwajibkan ngge'e nuru, yaitu calon menantu laki-laki tinggal bersama di rumah calon mertua selama masa pertunangan. ${ }^{23}$ Tujuan ngge'e nuru ini adalah proses penyesuaian antara calon menantu laki-laki dengan kehidupan calon mertua. Ketaatan, tanggungjawab, serta moral calon menantu benarbenar diuji sehingga calon mertuanya tidak ragu lagi menyerahkan anak perempuannya untuk dijadikan istri dan hidup bersama dalam berumah tangga. Selama proses ini calon menantu laki-laki tidak diperkenankan bergaul bebas dengan perempuan calon istrinya.

Setelah sampai pada wbatas waktu yang telah ditentukan untuk nge'e nuru tersebut, kemudian ditetapkanlah waktu dan saat untuk membicarakan soal mahar dan pelaksanaan pernikahan, kemudian dilanjutkan dengan acara pengantar mahar dari keluarga laki-laki kepada keluarga perempuan atau dalam masyarakat Bima lebih dikenal dengan acara $w a^{\prime} a c^{\prime} i$. Selanjutnya, prosesi upacara perkawinan dalam tradisi masyarakat Bima, biasanya dilakukan selama tiga hari tiga malam dengan beberapa rangkaian kegiatan sebagaimana berikut:

\section{a. Peta Kapanca}

Peta Kapanca adalah acara penempelan kapanca (daun pacar) yang telah digiling halus di atas telapak tangan calon pengantin wanita yang dilakukan pada malam hari pertama.

${ }^{23} \mathrm{Hal}$ ini sudah jarang terjadi, namun masih dilaksanakan khususnya di beberapa desa di Bima. 
Prosesi acara ini dilakukan secara bergilir oleh ibu-ibu pemuka adat, tokoh masyarakat dan tokoh agama. Peta Kapanca merupakan simbol bagi calon pengantin wanita bahwa sebentar lagi akan melakukan tugas sebagai istri atau ibu rumah tangga.

\section{b. Akad Nikah}

Memasuki hari kedua, dilangsungkan acara inti yaitu akad nikah atau lebih dikenal dalam masyarakat bima dengan londo dende. Acara ini diawali dengan mengiringi pengantin pria secara beramai-ramai oleh keluarga dan handai taulannya ke rumah pengantin perempuan dengan diiringi kesenian hadrah, yaitu melagukan lirik yang berisi pujian dan sanjungan pada Allah dan Rasul dengan diiringi pukulan rebana, sambil melakukan gerakan tertentu yang menjadi cirri khas kesenian hadrah dalam masyarakat Bima.

Setelah rombongan pengantin laki-laki sampai di rumah pengantin perempuan, maka dimulailah acara akad nikah yang diawali dengan khotbah nikah oleh penghulu serta dilanjutkan ijab qabul oleh wali dari pengantin perempuan terhadap pengantin laki-laki di hadapan saksi. Setelah selasai acara akad nikah, kemudian diadakan jamuan bagi para tamu dan undangan yang diakhiri dengan doa-doa oleh penghulu atau tokoh agama, dan menandakan berakhirnya rangkaian acara akad nikah tersebut.

\section{c. Boho Oindeu}

Boho oindeu merupakan prosesi selanjutnya pada hari ketiga, setelah dilakukan akad nikah pada hari sebelumnya. Prosesi boho oindeu ini adalah acara mandi dengan menyiramkan air kelapa yang dibelah dua di atas kepala kedua pengantin oleh tetua adat. Dalam hal ini, kedua pengantin berada dalam satu sarung yang dilingkari dengan benang putih. Hal ini bermaksud agar kedua pengantin baru tersebut tetap dalam satu ikatan 
perkawinan yang kuat dan abadi. Acara ini dilakukan sebelum pengantin bergaul sebagai suami istri. ${ }^{24}$

\section{d. Pamaco}

Pamaco adalah acara penutup dari rangkaian upacara perkawinan, yaitu acara sumbangan atau tanda mata (resepsi). Acara ini dilakukan di kediaman pengantin laki-laki, yang bertujuan untuk memperkenalkan pengantin kepada keluarga pihak laki-laki dan keluarga pihak perempuan, serta para undangan. Kemudian satu persatu menyampaikan ucapan selamat dan memberikan hadiah berupa uang atau barang. ${ }^{25}$ Dengan selesainya acara pamaco ini, maka menandakan berakhirnya seluruh rangkaian acara dalam prosesi upacara perkawinan. Beberapa proses dan tahapan-tahapan dalam upacara pernikahan tersebut, merupakan adat atau tradisi yang masih berlaku di kalangan masyarakat Bima.

Dari sekian prosesi upacara perkawinan, hanya ngge'e nuru dan boho oindeu yang hampir tidak dilaksanakan lagi dalam proses kegiatan upacara perkawinan. Hal ini disebabkan bergesernya pola pikir masyarakat seiring dengan perkembangan zaman yang semakin maju.

\section{Peta Kapanca Dalam Perkawinan Adat Bima}

\section{Pengertian Peta Kapanca}

Menurut Abdul Karim Aziz, tradisi peta kapanca ada semenjak masa pemerintahan Sultan Bima yang ke-2 yaitu Sultan Abil Khair Sirajudin. Pada saat itu Islam di Bima masih dalam proses sosialisasi dan adaptasi, sehingga berbagai tradisi dan budaya masyarakat dikemas dengan berbagai hal yang menarik perhatian masyarakat dan memiliki simbol-simbol keislaman. Peta kapanca memiliki simbol

\footnotetext{
${ }^{24}$ M. Fachrir Rahman, Islam di Bima, 43.
}

${ }^{25}$ Ibid., 44. 
keindahan yang dalam Islam yang merupakan salah satu hal yang di kehendaki oleh Allah dan Nabi. Masyarakat Bima pada saat itu sangat menyukai kesenian, sehingga Sultan Abil Khair Sirajudin mengemas peta kapanca sebagai wahana untuk mensosialisasikan ajararan Islam khususnya tatacara perkawinan yang sesuai dengan ajaran Islam. Peta kapanca hadir untuk menarik perhatian masyarakat agar pada keesokan harinya dapat dilaksanakan akad nikah sebagaimana yang diperintahkan Islam. ${ }^{26}$ Dengan demikian, peta kapanca hadir sebagai wahana untuk mengenalkan dan mengukuhkan Islam ditengah-tengah masyrakat Bima pada saat itu, sehingga masyarakat dapat menerapkan perintah-perintah agama sebagaimana yang diperintahkan oleh Allah dan Nabi.

Peta berasal dari bahasa Bima yang berarti menempelkan. Sedangkan kapanca berarti daun pacar (inai), jadi peta kapnaca berarti menempelkan daun pacar (inai) pada kuku pengantin wanita yang dilakukan oleh beberapa wanita adat yang berjumlah ganjil. Upacara peta kapanca ini merupakan salah satu rangkaian upacara terpenting pada prosesi perkawinan adat Bima sebagai tradisi budaya Bima yang melekat dalam upacara perkawinan. Peta kapanca merupakan simbol bagi calon pengantin wanita bahwa sebentar lagi akan melakukan tugas sebagai istri atau ibu rumah tangga.

\section{Tujuan Peta Kapanca}

Tradisi peta kapanca yang dilaksanakan dalam rangkaian perkawinan adat Bima memiliki tujuan untuk menghibur calon pengantin wanita dan sebagai pertanda berakhirnya masa lajang calon pengantin wanita, karena keesokan harinya setelah dilakukan akad nikah akan menjadi seorang istri atau ibu rumah tangga, dan menjadi peringatan bagi calon pengantin wanita tersebut bahwa dalam waktu yang tidak lama lagi akan melakukan tugas dan fungsi sebagai istri atau ibu rumah tangga. Di samping itu, tradisi peta

\footnotetext{
${ }^{26}$ Wawancara dengan Abdul Karim Aziz (Tokoh Adat Bima), pada tanggal 2010-2016.
} 
kapanca dimaksudkan untuk memberi contoh kepada para gadis lainnya agar mengikuti jejak calon pengantin wanita yang sedang mempersiapkan diri untuk menjadi seorang istri yang akan mengakhiri masa lajangnya sehingga mereka dapat mengambil hikmah. ${ }^{27}$ Selain tujuan yang berkaitan dengan mengakhiri masa lajang calon pengantin dan persiapan untuk menjadi istri atau ibu rumah tangga, Abdul Karim Aziz menjelaskan bahwa selain tujuan tersebut, tradisi peta kapanca dimaksudkan juga agar kehidupan calon pengantin nantinya indah seperti indahnya daun pacar yang menempel di tangan pengantin wanita tersebut, dan diharapkan mahligai pernikahannya melekat seperti melekatnya daun pacar pada tangan sang pengantin tersebut. ${ }^{28}$

\section{Prosesi Peta Kapanca}

Tradisi peta kapanca biasanya dilakukan oleh masyarakat Bima pada malam hari sebelum acara akad nikah dan resepsi pernikahan dilaksanakan. Sebelum prosesi peta kapanca dimulai terdapat beberapa rangkaian kegiatan pra acara, yaitu terlebih dahulu dilakukan acara sangongo atau mandi uap dengan bunga-bunga, atau yang lebih dikenal oleh masyarakat Bima dengan acara boho oi mbaru. Boho oi mbaru ini dilakukan oleh inang pengasuh pengantin sebelum pengantin wanita dirias dan diarak ke pelaminan peta kapanca. Selanjutnya, pengantin wanita dirias layaknya riasan pengantin serta memakai pakaian adat Bima. Prosesi selanjutnya adalah acara kalondo wei, yang dimulai dengan mengusung calon pengantin wanita dengan pabule (tandu) oleh saudara laki-lakinya ataupun karib kerabatnya yang laki-laki dan diiringi dengan $h a d r a h^{29}$ dari rumah inang pengasuh calon pengantin wanita menuju uma ruka. ${ }^{30}$

\footnotetext{
${ }^{27}$ Wawancara dengan Jafar Umar al-Idrus, pada tanggal 8-10-2016

${ }^{28}$ Wawancara dengan Abdul Karim Aziz, pada tanggal 20-10-2016

${ }^{29} \mathrm{Hadrah}$ adalah salah satu kesenian Islam yang mendendangkan shalawat dengan menggunakan rebana yang dimainkan oleh beberapa orang laki-laki.

${ }^{30} \mathrm{Uma}$ ruka adalah rumah pengantin perempuan tempat dilaksanakannya prosesi peta kapanca.
} 
Selama perjalanan menuju uma ruka, para pengusung pabule sambil bergoyang-goyang mengikuti irama rebana hadrah yang mengiringi perjalanan tersebut, sehingga pabule dan calon pengantin wanita yang berada di atasnya juga ikut bergoyang. Setelah sampai di uma ruka, calon pengantin wanita disambut oleh kedua orang tuanya dan ketika diturunkan dari pabule langsung digendong oleh orang tua laki-lakinya menuju pelaminan tempat akan dilangsungkannya prosesi peta kapanca. Rangkaian acara selanjutnya adalah prosesi peta kapanca sebagai acara inti yang dihadiri oleh tamu undangan dari kaum ibu dan kelompok jiki kapanca dari kaum bapak yang akan mengiringi prosesi peta kapanca tersebut, dengan susunan acara sebagai berikut:

Pertama, pembukaan acara oleh MC dan dilanjutkan dengan pembacaan kalam Ilahi. Kedua, pembacaan jiki kapanca yang dipimpin oleh tokoh agama dan tokoh adat. Jiki kapanca berisi pembacaan sya'ir maulid syaraful anam, pembacaan tersebut terus dilanjutkan sampai pada mahalal qiyam dan ditandai dengan pembacaan jiki kapanca sambil berdiri, maka prosesi ketiga adalah dimulainya prosesi peta kapanca yang terus diiringi oleh pembacaan jiki kapanca dan prosesi peta kapanca dimulai oleh tokoh adat wanita kemudian dilanjutkan oleh ibu-ibu tamu undangan yang lainnya sampai berjumlah ganjil dan prosesi peta kapanca diakhiri oleh ibu kandung dan calon mertua wanita, selanjutnya akhir dari jiki kapanca adalah pembacaan do'a yang dipimpin oleh tokoh agama yang memimpin jiki kapanca. Sebelum acara ditutup, dipersilahkan para tamu undangan untuk mengambil rangkaian bunga telur yang menghiasi pelaminan peta kapanca, dengan demikian maka berakhirlah seluruh rangkaian prosesi peta kapanca.

\section{Wajah Islam Nusantara Pada Tradisi Peta Kapanca Dalam Perkawinan Adat Bima}

Sebelum Islam masuk ke Bima telah berkembang dua lapisan budaya dasar yaitu budaya Bima asli yang merupakan hasil cipta, rasa dan karsa masyarakat Bima selama berabad-abad, dan kedua 
kebudayaan Hindu yang datang kemudian setidaknya memberi pengaruh pada masyarakat Bima walaupun masyarakat Bima tidak menganut agama Hindu.

Penyebar generasi Islam pertama di Bima sadar dan mengetahui hal tersebut sehingga ketika mereka mulai berdakwah tentang Islam, tidak berusaha menghapus akar budaya tersebut, akan tetapi akar budaya dipertahankan, dengan tidak memaksa Islam secara formalistik. Seprti halnya tradisi dan budaya Bima, Islam datang bukan menghapusnya tetapi memanfaatkannya dengan menjadikannya media dakwah, itulah yang dilakukan oleh para muballigh dan sultan.

Berbagai tradisi dan budaya dalam prosesi perkawinan adat Bima tidak serta merta dihilangkan karena tidak sesuai dengan ajaran Islam. Akan tetapi para muballigh dan sultan mencari jalan keluar dengan menyisipkan nilai-nilai Islam dalam prosesi perkawinan tersebut, sehingga masyarakat dengan gampang mengetahui dan beradaptasi dengan ajaran dan nilai-nilai keislaman.

Diantara prosesi penting dalam perkawinan adat Bima adalah tradisi peta kapanca. Tradisi peta kapanca didesain oleh para muballigh dan sultan sebagai tradisi yang dapat disisipi nilai-nilai keislaman. Pada mulanya tradisi peta kapanca sudah dikenal oleh masyarakat Bima pra Islam sebagai salah satu ritual untuk mempersiapkan dan mengantarkan calon pengantin wanita menjadi seorang istri dan ibu rumahtangga yang diiringi dengan pembacaan mantra-mantra dan persembahan sesajen agar kelak dapat menjadi istri dan ibu rumahtangga yang baik. Ketika Islam hadir menjadi agama resmi kesultanan dan masyarakat Bima, tradisi peta kapanca tetap saja sebagai ritual untuk mempersiapkan dan mengantarkan calon pengantin wanita menjadi istri dan ibu rumahtangga, tetapi dalam pelaksanaan dan prosesinya tidak lagi diiringi dengan mantra dan sesajen, namun diganti dengan bacaan al-Qur'an, shalawat dan do'a.

Akulturasi Islam dan budaya Bima sangat kental sekali pada tradisi peta kapanca ini, dimulai dari prosesi boho oi mbaru yang diiringi dengan bacaan shalawat dan do'a dengan harapan agar 
calon pengantin wanita sebelum melangsungkan akad nikah pada keesokan harinya bersih secara lahir maupun batin sehingga mendapat keberkahan dan rahmat dari Allah swt.

Sebagai salah satu kesenian Islam hadrah hadir dalam mengiringi prosesi kalondo wei. Begitu juga dengan pembacaan ayat suci alQur'an sebagai pembuka saat acara prosesi peta kapanca, dilanjutkan dengan pembacaan jiki kapanca yang berisi maulid syaraful anam sebagai do'a dan harapan agar calon pengantin wanita menjadi istri yang solehah sebagaimana anak keturunan Rasulullah. Bilangan ganjil bagi para ibu-ibu tamu undangan dalam prosesi peta kapanca menunjukkan nilai keislaman yaitu kesukaan Allah terhadap sesuatu yang ganjil, begitu juga dengan hiasan bunga-bunga telur di samping kanan dan kiri pelaminan menandakan keagungan asma' Allah yang berjumlah sembilan puluh sembilan.

Seiring dengan perubahan waktu dan zaman, sekarang ini praktek-praktek yang masih dilakukan oleh masyarakat tersebut, khususnya pada tradisi peta kapanca dalam perkawinan adat Bima, oleh sebagian kalangan masyarakat Bima itu sendiri dianggap sebagai perilaku yang menyimpang dari syari'at Islam.

Isu bid'ah menjadi isu yang digunakan oleh satu kelompok agama pada praktek keagamaan yang dilakukan oleh kelompok agama lainnya. Bhakan bid'ah adalah kata sekaligus isyu yang mewarnai perjalanan umat Islam. Dalam konteks literal kata bid'ah berarti " sesuatu yang dimuali dan diciptakan tanpa ada contoh lebih dahulu, dan dimulai setelah ia tidak ada sebelumnya. Dengan kata lain bid'ah mengandung arti sesuatu yang baru, sesuatu yang tidak memiliki contoh terdahulu.

Akulturasi Islam pada tradisi peta kapanca dalam perkawinan adat Bima atau dalam istilah lain disebut dengan pribumisasi Islam oleh sebagian kalangan berpotensi mempraktekkan bid'ah dalam Islam yang tidak memiliki landasan tekstual maupun kesejarahan yang dilakukan oleh generasi Sahabat dan para pengikutnya. Membuat sesuatu yang baru dalam Islam yang tidak berdasar pada tekstual dianggap sebagai kesalahan besar dalam beragama. 
Padahal teks hadis yang menyebut tentang bid'ah tersebut ditafsiri dengan dalil yang menyebutkan bid'ah secara muqayyad. Metode semacam ini dalam istilah ushul fiqh dikenal dengan "hamlu almutlaq 'ala al-muqayyad". Berdasarkan kaidah ushul fiqh tersebut, para ulama membagi bid'ah menjadi dua; yaitu bid'ah sayyi'ah dan bid'ah hasanah.

Bid'ah sayyi'ah tidak membawa manfaat dan juga tidak memiliki kekuatan tekstual yang mendukung argumentasinya, sedangkan bid'ah hasanah terdapat dalil yang bisa dijadikan kekuatan terhadap praktek keislaman yang dilakukannya, sehingga bid'ah hasanah tidak hanya dimaklumi melainkan bagus untuk dipraktekkan.

Ritual-ritual keislaman yang menyatu dengan tradisi peta kapanca dalam perkawinan adat Bima merupakan bagian dari praktek bid'ah yang baik, tentunya boleh dilakukan dan bahkan harus terus dilestarikan. Karena selain memiliki nilai-nilai keislaman sebagai simbol syi'ar Islam, juga memiliki nilai-nilai kebudayaan lokal yang harus dipertahankan agar generasi seterusnya dapat mengetahui dan memahami harmonisasi antara Islam dan kebudayaan Bima, khusussnya tradisi peta kapanca.

Dalam Pribumisasi Islam, setiap individu atau kelompok masyarakat yang telah memiliki sistem budaya sendiri sebagai hasil dari karya ciptanya sendiri, dibiarkan dan bahkan dimotivasi untuk terus berkarya dan menemukan sesuatu yang baru yang lebih baik dari sebelumnya, tentunya melalui muatan penyematan spirit ajaranajaran Islam. Tradisi-tradisi yang dimiliki oleh tiap budaya lokal terus dikembangkan dengan memperhatikan juga aspek spiritualitas dan tradisi Islam.

Proses pribumisasi Islam pada tradisi peta kapanca itulah yang kemudian membentuk pola atau corak Islam yang khas Bima yang merupakan wajah Islam Nusantara, yaitu Islam yang bercirikan Indonesia, yang memiliki gabungan antara nilai Islam teologis dengan nilai-nilai tradisional lokal, budaya, dan adat Istiadat di Tanah Air, khususnya di Bima. Dengan demikian, pribumisasi Islam pada tradisi peta kapanca adalah caranya, dan hasil dari akulturasi Islam 
Tajdid: Jurnal Pemikiran Keislaman dan Kemanusiaan, Vol. I No. I April 20 I7: I-24

pada tradisi peta kapanca dalam perkawianan adat Bima itulah kemudian menjadi salah satu wajah Islam Nusantara.

\section{Penutup}

Penyelenggaraan peta kapanca dalam masyarakat Bima telah menjadi bagian dari tradisi masyarakat. Hadirnya peta kapanca dalam perkawinan adat Bima, menjadikan peta kapanca sebagai bagian dari respon masyarakat terhadap kebudayaan yang berbasis Islam. Pelaksanaan peta kapanca ini terdiri dari beberapa prosesi, dimulai dari prosesi pra peta kapanca berupa prosesi boho oi mbaru atau mandi uap dengan bunga-bunga, prosesi selanjutnya adalah kalondo wei, yang dimulai dengan mengusung calon pengantin wanita dengan pabule (tandu) oleh saudara laki-lakinya ataupun karib kerabatnya yang laki-laki dan diiringi dengan hadrah menuju uma ruka. Rangkaian acara selanjutnya adalah prosesi peta kapanca sebagai acara inti yang dihadiri oleh tamu undangan dari kaum ibu dan kelompok jiki kapanca dari kaum bapak yang akan mengiringi prosesi peta kapanca tersebut.

Bentuk-bentuk akulturasi Islam dengan budaya Bima pada tradisi peta kapanca dapat dilihat pada; pertama, pada saat prosesi boho oi mbaru atau mandi uap dengan bunga-bunga yang dimulai dengan pembacaan shalawat dan do'a. Kedua, pada saat prosesi kalondo wei nuansa Islam begitu jelas dengan adanya iringan hadrah yang merupakan salah satu kesenian Islam. Ketiga, prosesi peta kapanca yang dimulai dengan pembukaan dengan membaca basmallah dan dilanjutkan dengan pembacaan kalam ilahi yang kemudian dilanjutkan dengan jiki kapanca yang berisi pembacaan maulid syaraful anam. Keempat, prosesi peta kapanca yang dilakukan oleh para tokoh dan tetuah adat serta tamu undangan yang berjumlah ganjil, melambangkan bahwa Allah swt. menyukai sesuatu yang ganjil dan hiasan bunga-bunga telur yang terpasang di samping kanan dan kiri pelaminan yang berjumlah sembilan buluh sembilan buah, melambangkan asmaul husna. 


\section{Daftar Pustaka}

Abdullah, Abdul Gani. Peradilan Agama dalam Pemerintahan Islam di Kesultanan Bima (1947-1957. Yogyakarta: Genta Publishing, 2015.

Amin, Ahmad. Ringkasan Sejarah Bima. Bima: Kantor Kebudayaan Kabupaten Bima, 1971.

Barker. Cultural Studies, Teori dan Praktek, terj. Tim Kunci Cultural Studies Center. Yogyakarta: Bentang, 2005.

Campbell, Tom. Tujuh Teori Sosial, Sketsa Penilaian, Perbandingan. Yogyakarta : Kanisius, 1994.

Depag RI. 2000. Dinamika Kerukunan Hidup Beragama di Daerah, Laporan Observasi. Jakarta: Proyek Pembinaan Kerukunan Hidup Beragama.

Hamzah, Muslimin. Ensiklopedia Bima. Bima: Pemerintah Kabupaten Bima, 2004.

Ismail, M. Hilir. Kebangkitan Islam di Dana Mbojo (Bima). Bogor: Binasti, 2008.

Jamil, Abdul et.al. Islam dan Budaya Lokal. Yogyakarta: Pokja Akademik, 2015..

K. Garna, Judistira. Ilmu-ilmu Sosial Dasar Konsep-Posisi. Bandung: PPs UNPAD, 1996..

Kahmad, Dadang. Sosiologi Agama. Cet. Ke-4. Bandung: PT. Remaja Rosdakarya, 2009.

Koentjoroningrat. Metode-Metode Penelitian Masyarakat, Cet. Ke-3, Jakarta: Gramedia, 1991.

Rahman, M. Fachrir. Islam di Bima; Kajian Historis tentang Proses Islamisasi dan Perkembangannya sampai Masa Kesultanan. Yogyakarta: Genta Press, 2008.

. Pernikahan Di Nusa Tenggara Barat: Antara Islam dan Tradisi. Mataram: LEPPIM IAIN Mataram, 2013.

Sodiqin, Ali. Antropologi al-Quran, Model Dialektika Wahyu dan Budaya. Yogyakarta: Ar-Ruzz Media, 2008. 
Tajdid: Jurnal Pemikiran Keislaman dan Kemanusiaan, Vol. I No. I April 20 I7: I-24

Soekanto, Soerjono. Talcott Parsons Fungsionalisme Imperatif . Jakarta: CV. Rajawali, 1986.

Solikhin, Muhammad. Ritual dan Tradisi Islam Jawa. Yogyakarta: NARASI, 2010.

Suprayogo, Imam dan Tabrani. Metodologi Penelitian Sosial-Agama. Cet. Ke-2. Bandung: Remaja Rosdakarya, 2001.

Tajib, Abdullah. Sejarah Bima ( Dana Mbojo). Jakarta: Harapan Masa PGRI, 1995.

Wahid, Abdurrahman et.al. Islam Nusantara dari Ushul Figh Hingga Paham Kebangsaan. Bandung: Mizan Pustaka, 2015.

Yousda, Ine Amirman dan Zainal Arifin. Penelitian dan Statistik Pendidikan. Jakarta: Bumi Aksara, 1992. 